\title{
Pendampingan Pelajar/Remaja Dalam Penanggulangan Klithih Di Kabupaten Kulon Progo
}

\author{
Mukhtar Zuhdi, Bagus Sarnawa \\ Program Studi Hukum, Fakultas Hukum Universitas Muhammadiyah Yogyakarta \\ Jalan Brawijaya, Tamantirto, Kasihan, Yogyakarta, 55183, Indonesia \\ Phones: +62-274-387656, Fax: +62-274-387646 \\ Email: mukhtarzuhdi@umy.ac.id \\ DOI: $10.18196 / p p m .37 .266$
}

\begin{abstract}
ABSTRAK
Perbuatan klitih yang disertai dengan tindakan kekerasan yang cukup marak di wilayah Yogyakarta. Klitih telah banyak membawa korban dan nyawa manusia, sehingga menimbulkan perhatian dan sorotan masyarakat bahwa perbuatan klitih telah bergeser dari asal muasal klith yang dulunya hanya merupakan perilaku budaya lokal masyarakat Yogyakarta dan sekitarnya yang tidak bersifat negatif dan tidak berdampak merugikan orang lain, menjadi suatu perbuatan kriminal yang menyeramkan dan tentunya harus dicegah secara preventif dan atau dilakukan penindakan secara represif.

Problem yang dihadapi oleh mitra pengabdian SMA Muhammadiyah 3 (MUGA) Yogyakarta adalah bagaimana model dan peran guru dalam penanggulangan perbuatan dan atau korban klitih bagi para siswanya yang tepat dan efektif. Menurut data kriminal dari Polda Daerah Istimewa Yogyakarta, pelaku dan atau korban perbuatan klitih didominasi oleh pelajar atau remaja. Untuk menjaga dan melindungi para siswa SMA Muhammadiyah 3 Yogyakarta agar terhindar dari perbuatan dan atau korban klitih, perlu dilakukan pendampingan dan advokasi yang tepat dan efektif.
\end{abstract}

Model yang ditawarkan dalam pengabdian masyarakat dengan skema Program Kemitraan Masyarakat (PKM) oleh tim pengabdi dari Fakultas Hukum Universitas Muhammadiyah Yogyakarta adalah:

Penyuluhan hukum dan atau Focus Group Discussion (FGD) dalam rangka meningkatkan pemahaman dan kesadaran masyarakat akan bahayanya serta perlunya penanggulangan perbuatan klitih dengan kekarasan oleh pelajar/remaja di Yogyakarta, dengan melibatkan peserta para guru, para orang tua/wali siswa, serta para siswa.

Pendampingan dan advokasi secara persuasif terhadap para pelajar/remaja yang berpotensi sebagai pelaku perbuatan dan atau korban klitih dengan kekerasan di Yogyakarta.

Efektivitas penanggulangan perbuatan klitih yang disertai kekerasan yang merupakan tindakan kriminal yang banyak melibatkan dan atau membawa korban para pelajar/remaja di Yogyakarta, tentunya harus dilakukan secara sinergis antara pihak sekolah, orang tua/wali siswa dan aparat kepolisian sebagai penegak hukum, sehingga upaya pencegahan secara prefentif dan penindakan secara represif dapat dilakukan secara optimal.

Pengabdian masyarakat dengan skema Program Kemitraan Masyarakat (PKM) adalah merupakan bagian kegiatan akademik, sebagai implemantasi salah satu dari Tri Dharma Perguruan Tinggi yaitu Dharma Pengabdian Masyarakat. Oleh karena itu harus dilaksanakan sesuai dengan tahapan dan prosedur kegiatan akademik, di mana dalam kegiatan pengabdian masyarakat dalam pelaporannya harus disertai luarannya. Adapun luaran dari Pengabdian Masyarakat ini adalah berupa artikel ilmiah dengan tema "Pendampingan Masyarakat dalam Penanggulangan Perbuatan Klitih oleh Pelajar di Yogyakarta" yang akan dimuat dalam Jurnal terakreditasi nasional.

Kata Kunci :, Klithih, Remaja, Penyuluhan

\section{PENDAHULUAN}

Klitih pada awalnya bukan merupakan nomenklatur dalam ilmu hukum dan kriminologi, melainkan merupakan nomenklatur budaya lokal yang dikenal dalam lingkungan sosial khususnya di wilayah Yogyakarta.

Klitih merupakan perbuatan yang dilakukan seseorang baik sendiri maupun bersama-sama keluar dari rumah pada waktu malam hari yang tidak memiliki tujuan khusus, melainkan sekadar bersantai, menikmati suasana malam hari, ngobrol ngalor ngidul, sambil menikmati minuman dan makanan murah di suatu 
tempat yang tidak jauh dari rumahnya, biasanya di warung angkringan, kongko-kongko bahkan hingga sampai larut malam.

Dalam perkembangannya, perbuatan klitih ternyata tidak sekadar keluar malam kongko-kongko di warung angkringan, melainkan telah banyak dicoreng oleh perilaku nakal dan jahat yang sangat tercela, bahkan perbuatan kriminal. Contoh perbuatan nakal dan tercela yang banyak dilakukan dalam perbuatan klitih adalah mabuk-mabukan, ngepil, narkotika, malak, ngamuk, merusak lingkungan, menganiaya bahkan ada yang membunuh orang lain. Oleh karena itu, jika perbuatan klitih yang disertai tindakan kekerasan secara hukum pelakunya dapat dituntut dan dipertanggungjawabkan secara hukum pidana.

Berdasarkan catatan kepolisian, selama tahun 2018 setidaknya ada 13 kasus klitih dengan korban jiwa dua orang. Rinciannya, di Kabupaten Bantul tiga kasus, Sleman empat kasus, Kulonprogo dua kasus, Kota Yogya tiga kasus, Gunungkidul satu kasus. Kabid Humas Polda DIY AKBP Yulianto mengungkapkan dari beberapa yang kejadian klitih yang behasil diungkap, beberapa pelaku berstatus sebagai pelajar. Dari 13 kasus klitih terjadi di Yogyakarta tersebut, dua korban meninggal dunia. (Tribunjogja.com).

Untuk mencegah kasus klitih terulang, menurut Yulianto, pihak kepolisian sudah melakukan sejumlah upaya. mulai dari patroli rutin dan razia pada malam hari, kerja sama dengan Dinas Pendidikan DIY melalui program polisi masuk sekolah hingga program-progam preventif lainnya.kita terus menggiatkan kegiatan razia dan patroli,"ucapnya. Selain itu, untuk mencegah kasus klitih, Yulianto menilai peran dari keluarga dan lingkungan juga sangat penting.

Menurut Kapolda DIY Irjen.Pol Ahmad Dofiri, dibandingkan dengan tahun 2017 perbuatan klitih di wilayah hukum Polda DIY jauh berkurang, 2017 ada 48 kasus sedangkan 2018 turun berkisar separuhnya, katanya. Angka kasus klitih terus berkurang karena menurut Kapolda, pihak kepolisian dalam menanggulangi kasus tersebut bekerjasama dengan Dinas Pendidikan Pemuda dan Olahraga (disdikpora) untuk berusaha menekan kenakalan remaja. (tribunjogja)

Sebagai contoh kasus klithih yang menimpa korban salah seorang siswa SMA Muhammadiyah 1 Yogyakarta bernama Adnan Wirawan Ardiyanta. Mulanya mengisi waktu dengan berwisata bersama teman-teman sekolah. Senin, 12 Desember, Adnan Wirawan Ardiyanta, 16 tahun, di antara rombongan sepuluh sepeda motor, pergi ke pantai Ngandong, Gunungkidul. Pulangnya, para pelajar SMA 1 Muhammadiyah itu berpapasan dengan rombongan pelajar lain yang menaiki delapan sepeda motor, di ruas jalan perbatasan Gunungkidul dan Bantul, sekira 50 kilometer dari lokasi pantai. Kedua rombongan saling melirik. Keduanya saling menggeber motor. Kelompok pelajar itu, yang diduga sengaja menguntit teman-teman Adnan dari perseteruan lama antar-geng sekolah, lantas berbalik arah dan mengejar. Mengenakan cadar dan membawa celurit dan parang, para pelajar SMA 1 Muhammadiyah dikeroyok, disabet parang, ditusuk, dan dilempari batu. Sebagian teman Adnan yang berhasil menyelamatkan diri segera mencari dan melapor kepolisian terdekat. Kembali ke lokasi, enam kolega mereka terluka, salah satunya Adnan. Nahas, Selasa malam sekira pukul 19:30, Adnan tak bisa diselamatkan. Ia meninggal tanpa sempat dioperasi persis ketika sang ayah, Agus Riyanto, sedang meneken prosedur operasi. Nyawa putranya melayang akibat pendarahan organ dalam. "Tusukan senjata tajam menembus mengenai ginjalnya sehingga mengakibatkan pendarahan parah,” tutur Agus kepada media. (tirto.id).

Apa yang menimpa Adnan, dan teman-teman seusianya, dikenal dalam istilah di Yogyakarta sebagai klithih, bahasa Jawa untuk aktivitas mencari angin di luar rumah atau keluyuran. Namun, dalam dunia kekerasan remaja, ia berubah jadi sebutan yang seram. Sematan klitih berkembang sebagai aksi kekerasan dengan senjata tajam atau tindak-tanduk anak di bawah umur di luar kelaziman.

Berdasarkan hukum pidana, perbuatan klithih yang disertai dengan tindakan kekerasan seperti dalam kasus klitih yang menimpa Adnan Wirawan Ardiyanta seperti tersebut di atas merupakan tindak pidana berat sebagaimana diatur dalam Pasal 354 ayat (2) KUHP tentang penganiayaan berat yang berakibat kematian, dengan ancaman pidana penjara maksimum sepuluh tahun atau Pasal 338 KUHP tentang pembunuhan, dengan ancaman pidana maksimum lima belas tahun. 


\section{METODE PELAKSANAAN}

Pelaksanaan Pengabdian ini akan dilaksanakan dengan beberapa metode, antara lain:

1. Penyuluhan Hukum dan Agama

Penyuluhan hukum dilakukan untuk memberikan pengetahuan pada para siswa terkait dengan perbuatan klithih dengan kekerasan yang bertentangan dengan peraturan perundang-undangan. Dengan penyuluhan hukum ini maka target yang diharapkan adalah para siswa mengetahui permasalahan klithih dengan kekerasan dan seterusnya terbangun kesadaran untuk mentaati peraturan perundang undangan. Penyuluhan agama dilakukan untuk memberikan pemahaman kepada para siswa tentang kehidupan manusia selalu diawasi oleh Allah SWT setiap perbuatan baik yang benar atau salah akan mendapatkan balasan dari Allah SWT.

\section{Focus grup discussion}

Focus Group Discussion dilaksanakan untuk mengekspolarasi persoalan-persoalan yang dihadap para remaja dan selanjutnya memberikan solusi pada para siswa terkait dengan persoalan tersebut. FGD ini juga dilakukan dengan pihak guru dan perwakilan orang tua.

3. Pendampingan atau advokasi

Pendampingan dan advokasi dalam hal menjadi pelaku atau korban dalam perbuatan klithih dengan kekerasan.

\section{HASIL DAN PEMBAHASAN}

Dalam pelaksanaan pengabdian ini, awalnya akan dilaksanakan di SMA Muhammadiyah 3 Yogyakarta, namun demikian akibat adanya pendemi covid 19, di mana kegiatan belajar mengajar dilakukan secara online, maka pihak sekolah tidak mampu untuk mengumpulkan siswa maupun komite sekolah ke sekolah. Apabila pihak sekolah akan mengumpulkan siswa maupun komite sekolah maka harus melalui proses perizinan. Di sisi lain, pelaksanaan pengabdian ini harus dilakukan dengan tatap muka karena akan melakukan penyuluhan, focus group discussion dan pendampingan yang kegiatan-kegiatan tersebut harus direkam sebagai bukti fisik telah dilakukan kegiatan pengabdian ini.

Oleh sebab itu kemudian, kegiatan pengabdian ini atas izin Kepala LP3M UMY melalui Wakil Dekan Bidang Akademik, dipindahkan lokasinya di Pesantren Pondok Asuhan Muhammadiyah Putra Daarusubusi Beji Wates, Kulon Progo.

Kegiatan pengabdian telah berhasil dilaksanakan dengan melakukan penyuluhan kepada para santri Pesantren Pondok Asuhan Muhammadiyah Putra Daarusubusi Beji Wates, Kulon Progo dan para remaja di sekitar Pesantren Pondok Asuhan Muhammadiyah Putra Daarusubusi Beji Wates, Kulon Progo.

Di samping itu juga melakukan FGD dengan para ustadz dan ustadzah serta perwakilan orang tua dalam upaya mendiskusikan persoalan-persoalan anak-anak usia remaja serta mencarikan solusinya.

Hasil FGD menunjukkan bahwa pihak ustadz dan ustadzah menginginkan adanya kegiatan lanjutan berupa pendampingan hukum, agama dan psikologi. 


\section{3}
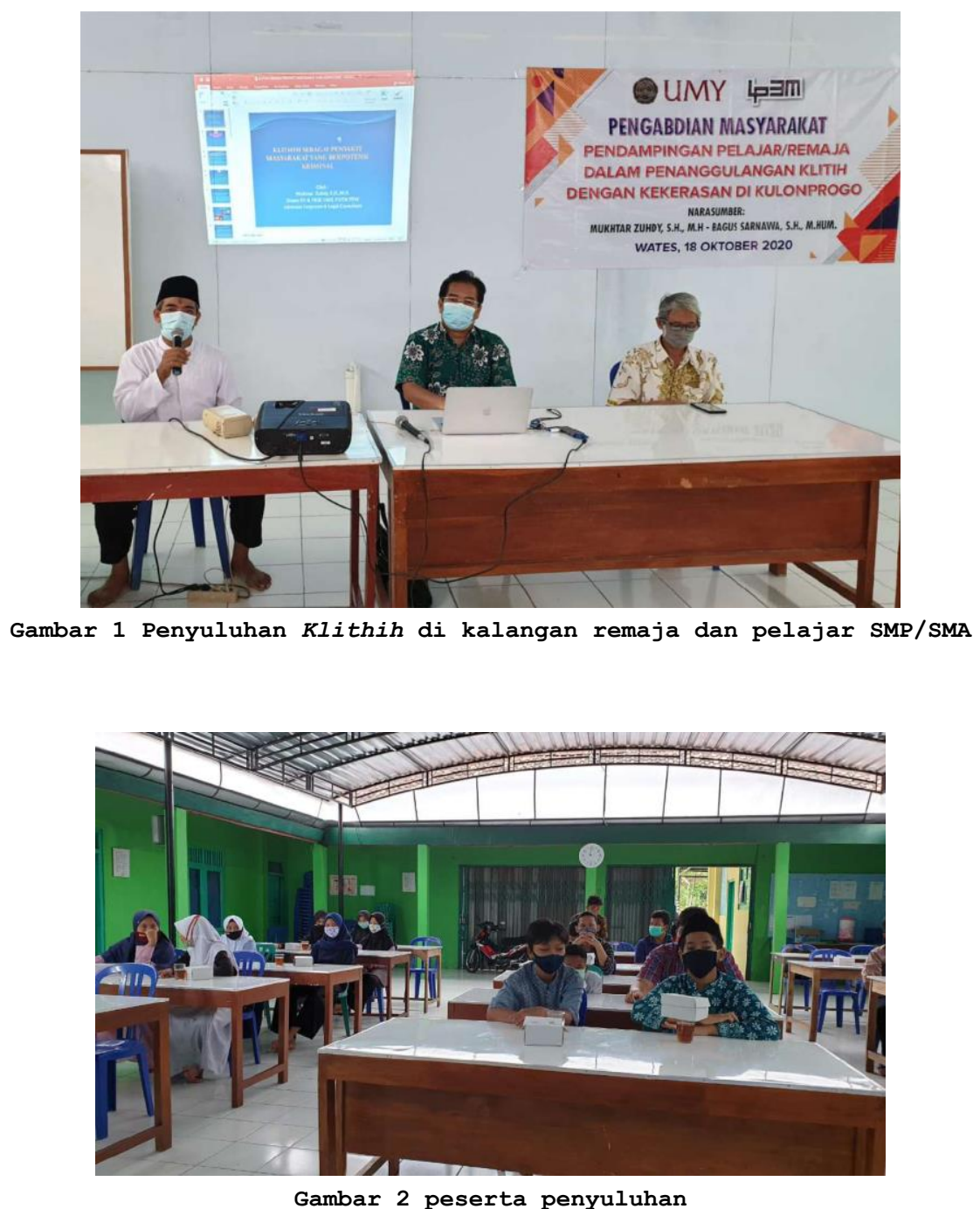

\section{SIMPULAN}

1. Kegiatan pengabdian telah terlaksana dengan baik seperti penyuluhan dan pendampingan terhadap pengasuh pondok pesantren dan pelajar serta remaja di pesantren dan sekitar pondok pesantren.

2. Kegiatan yang perlu ditindaklanjuti adalah pendampingan kepada orang tua dan penyuluhan dari perspektif psikologi.

\section{UCAPAN TERIMA KASIH}

Ucapan terima kasih, pengabdi sampaikan kepada :

1. Rektor Universitas Muhammadiyah Yogyakarta

2. Kepala LP3M Universitas Muhammadiyah yang telah memberikan dana untuk kegiatan pengabdian masyarakat berdasarkan Surat penetapan Kepala LP3M Universitas Muhammadiyah Yogyakarta Nomor 031/PEN-LP3M/I/2020

3. Bapak Drs Kadirun Mudir Pesantren Pondok Asuhan Muhammadiyah Putra Daarusubusi Beji Wates kulon Progo

4. Orang tua dan remaja yang bertempat tinggal di sekitar wilayah Pesantren Pondok Asuhan Muhammadiyah Putra Daarusubusi Beji Wates kulon Progo 